\title{
The Effects of Leadership Style on Students Performance
}

\author{
Tesfaye Demissie Hailegebreal \\ Department of Chemistry, Debre Berhan University, \\ P. O. Box 445, Debre Berhan, Ethiopia \\ Ayalew Temesgen \\ Department of Chemistry, Haramaya University, \\ P.O. Box 138 Dire Dawa
}

\begin{abstract}
The organization of the leader has to be ready in all aspects of activities to lead effectively. Similarly, department heads are responsible for promoting good teaching and learning practices among teachers and students. This study was aimed to examine which leadership style used by Natural and computational college of Debre Berhan University and the relationship between the leadership style and college effectiveness in students' performance.

The sample were 95 females and 125 males; 16 administrators (college head, associate deans, coordinators, department heads, and officers), and 24 student monitors with available sampling, and out of 312 teachers, 180 with simple random sampling. The researchers used questionnaires, focused group discussion and observation to collect data. The data was analyzed employed both qualitative and quantitative analysis and a descriptive survey design. The overall result indicated that transformational leadership and autocratic styles were highly applied than the remaining leadership wo leadership styles because its components are $(0.895,0.7140$ and $0.887,0.674)$ respectively revealed that these are the main components in leading the college while others are used moderately and rarely. It was also revealed that the selected college students and workers perform reasonably better. Moreover, both teachers and students were satisfied with their college leaders that indicated that the performance of teachers and students is the direct reflection of leadership styles. It was recommended that the college head and his subordinate coordinators should improve their way of transformational and autocratic leadership style since they were found as the best factor of student performance.
\end{abstract}

Keywords: leadership styles, student performance, University education, University context

DOI: $10.7176 / \mathrm{JEP} / 11-34-03$

Publication date: December $31^{\text {st }} 2020$

\section{INTRODUCTION}

\subsection{Background}

Leadership is a complex, multifaceted process concerned with the art of inspiring, motivating, and guiding followers in a particular direction which involves casting a vision, goal setting, and encouraging people to be successful(Fischer, Dietz, \& Antonakis, 2017). These leaders should promote happiness, unity, harmony, strength, and prosperity in society (Potocki \& Brocato, 1995)

And it is critical for the success and survival of all forms of organizations preparing objectives, building charming and attractive leadership. Leaders can clearly show the goal and objective the institution want to achieve. Visionary leaders can steer the organization towards great success(Silva, 2016). Leadership success is realized by quality results. Successful leaders have to develop both managerial and leadership behavior and traits. Therefore, the leader shows how to set objectives and implement them based on established rules and regulations (Zvavahera, 2014a).

Leadership is a personal commitment to make a difference in lives and success, however; it is under-utilized in many universities as most academics feel that they have nothing to do in contributing towards building human capabilities and capacities. This would normally lead to staff, stakeholders, and students being dissatisfied thereby leading to poor performance(Mishra, 2006).

"Quality is the totality of features and characteristics of a product or service that bear on its ability to satisfy stated or intended needs." the main concern of leader should be creating an inspired team that can produce or give these quality service(Ijaz Ahmad Tatlah, Iqbal, Amin, \& Quraishi, 2014). Education structure is the way in which educational programs are processed and institutions are administered and lead by a brilliant leader to mitigate the challenges(Kumpulainen, Kajamaa, \& Rajala, 2018). Our society demands training centers to increase the quality of their student learning. This pressure is falling on leaders. However, in most cases of colleges, they are occupied by routine work rather than focusing on improving student performance(Manning, 2017). Conversely, Colleges should provide enhanced flexibility and autonomy in managing their operation and resources according to the needs and abilities of students, to facilitate the development of quality education with their characteristics(Akalu, 2014). Research suggests effective college leaders must demonstrate targeted leadership skills, such as promoting professional growth among faculty and demonstrating efficacy in teaching methodology, there should be also 
collaborative partnerships between leaders and teachers may help unite efforts and overcome the weakness of the college learning processes(Akalu, 2014). Therefore, key questions that guided this research included, which style of leadership made department heads relevancy, instill passion, and provide effective leadership that inspires teachers through such challenging times, and can lead and achieve a positive stable environment where teachers view department heads and other coordinators as cooperative partners in the education process through modeling effective pedagogical strategies and tools? It also delt which type of leadership style enables to performs better. Understanding how the college head and its subordinate leadership style affect academic performance. This may give hints in revising the learning situation of this declining academic performance and quality of learning (Anyango, 2015).

Thus, this study aims to examine which leadership style affects students' academic performance and satisfies the working environment of the college.Taking these into account the following leading question are formulated.

1. What are the relations between leadership style and students' performance?

2. To what extent are college leadership style and different professional satisfaction are related in college on natural and computational college?

3. How do leaderships styles and and professionals job satisfaction affect students' academic performance?

\section{Review of related literature}

\subsection{Importance of leadership on students performance}

Leaders are the heart of the organization to achieve short and long-term goals and objectives. they can help the team to develop a shared understanding of organization's, mission, vision, and its activities, can give clear and convincing organizational direction to their folowers(Ojokuku, Odetayo, \& Sajuyigbe, 2012). Scholars say that leadership matters because effective leaders make a difference in people's 'career and live; empower followers and educate them on how to do their activites by taking appropriate actions that can facilitate change (Hina \& Hussain, 2019; Karadağ, Bektaş, Çoğaltay, \& Yalçın, 2015; Mlingwa, 2015; Sun \& Leithwood, 2015).

Leaders should know what is required to improve the quality of teaching and learning process the ones who can make use of the employees' capacity and inspire enthusiasm and hopefulness. In this case, leaders may get the best out of their employees and as a result increase their productivity (Hina \& Hussain, 2019; Karadağ, Bektaş, et al., 2015; Mlingwa, 2015; Sun \& Leithwood, 2015). Apart from the fact that the college head knows what to do, he/she knows when, how, and the reason for doing it, the consequence of improvement that brings about perfection on students' performance. It may therefore, be argued that a headteacher, who does not engage in actions consistent with instructional leadership, has a wrong perspective of the college's goals(Ouma, Lucy, \& John, 2015).

So that, the main job of the college head is to create an inspiring atmosphere that fosters competence, effective teaching, and learning. Therefore, the type of environment that exists in a college could be used as an instrument to measure the head teacher's effectiveness(TS \& Swamy, 2014; Vaismoradi, Bondas, Salsali, Jasper, \& Turunen, 2014). In light of the stated views, in the context of this project, leadership will be perceived as the ability of the college head to relate with the teachers such that the flairs that are embedded in individual teachers are liberated, causing them to constantly see and seize opportunities to improve organizational performance and enhance individual development; leadership is an integral part of this study(Beri \& SHU'AIBU).

\subsection{Types of leadership}

There are different perspectives concerning leadership and leadership style in terms of leading institutions and organizations. Leadership is associated with colleges and college administration in the educational sector. College leaders are expected to guide and motivate all employees and encourage them to meet the objective of the college (Karadağ, Çoğaltay, Bektaş, \& Yalçın, 2015).

\subsubsection{Autocratic (authoritarian) leadership}

An autocratic leader is one who decides and comes up with a solution for the entire group on their own with little or no discussion with other team members. decide on their perception until they convince the subordinates(De Cremer, 2006; Van Vugt, Jepson, Hart, \& De Cremer, 2004).

\subsubsection{Laissez -faire or free rein leaders}

Laissez-faire or free rein leaders are leaders who give very little guidance when dealing with group issues provide overall authority and control to their subordinates(Al-Ababneh, 2013). They assert that free-rein avoid holding power and responsibilities by one higher official, improves job satisfaction of the subordinates as well as ensuring that the potential of the subordinates can be optimally utilized(Howard, 2005; Khan, 2012; Martirosyan, Saxon, \& Wanjohi, 2014).

\subsubsection{Democratic (participative) leadership}

Leadership is very relaxed and participative in which the leader invites the subordinates or team members to participate in the decision respecting them and their input into overall processes(Sheshi \& Kërçini, 2017). Democratic leaders consistently take input and advice from those members or followers in a decision making process within the mission setting, many of the participants displayed this kind of leadership by obtaining 
suggestions from other members of the group to come to a team consensus when trying to solve a problem or an issue(Choi, 2007; Iqbal, Anwar, \& Haider, 2015; Moynihan \& Pandey, 2010; Snell \& Swanson, 2000).

\subsubsection{Transformational Leadership}

Leaders are inspiring, the team members with a shared vision, they spend most of their time by guiding and discussing with their subordinates, they are not willing to do everything but delegating responsibilities amongst their teams and when they are observing weakness they are ready enthusiastically to help their subordinates with detail and reasonable guiding principle (Ayoko \& Chua, 2014; Bass \& Riggio, 2006; Boysen, Kelly, Raesly, \& Casner, 2014; Nielsen, Yarker, Brenner, Randall, \& Borg, 2008). These can create and sustains a context that maximizes human and organizational capabilities; facilitate manifold levels of transformation, and align them with core values and a unified purpose. Make organizations charisma a special leadership style commonly associated with transformational leadership; extremely powerful, extremely essential for teamwork(S.Nanjundeswaraswamy \& Swamy, 2014; Wang, 2014).

\subsection{Character and skills associated with effective leadership}

They are well aware of student learning requirements, academic standards, and appropriate instructional strategies that lead to student learning, giving priority to decision processes that impact the quality of student learning and teacher proficiency, communicating the links between academic standards, effective instruction, analyzing data, using critical thinking, and problem-solving, evaluating decisions for effectiveness, uses timely, effective, and transparent processes for making decisions, equity, intended and actual outcomes, and revisions as needed and incorporating data-driven decision making with effective technology integration to analyze college results (Chai \& Kong, 2006; Zvavahera, 2014b)

Educational leaders play an important role to make teaching and learning more effective and to give quality education to students. The leadership style of ahead of the college depends on the leaders' assumptions about the human being, human nature, and human learning. These assumptions consciously and unconsciously are the main foundation for decision making and choosing a leadership style (Akessa \& Dhufera, 2015a, 2015b; Khan, 2012; Martirosyan et al., 2014)

\section{RESEARCH METHODOLOGY}

\subsection{Population and sample of the study}

The population of the study covered eight departments' of Natural and computational science college:-24 students monitors, 16 administrators'(college heads, associate deans, coordinators, and, department heads) and 312 teachers; among these 24 student monitors and 16 administrators' with available sampling, and 180 teachers with simple random sampling were taken as a sample principle(Cohen, Manion, \& Morrison, 2005; Creswell, 2009; Gray, 2004; Robinson, 2007).

\subsection{Method of analysis and instruments used in the study}

Schedule questionnaires, observation, and focused group discussions were employed to collect data. The mixed qualitative and quantitative methods were used, then the qualitative data were analyzed using pattern match and quantitative data was analyzed using inferential analysis of component analysis employed with the help of SPSS 21 soft were package principle(Cohen et al., 2005; Creswell, 2009; Gray, 2004; Robinson, 2007).

\subsection{Reliability and validity of the instruments}

The reliability of the instruments was checked through Cronbach's alpha by using pilot test collected from 15 teachers and students that were not included in the main samples. And the content validity was checked using four experts from education college by using rating each question (poor, fair-good, and very good). According to their comments and suggestion, the questions were corrected and rearranged. The Cronbach's alpha and validity were $\mathbf{0 . 8 5 2}$ and $\mathbf{0 . 9 2}$ respectively.

\section{RESULT AND DISCUSSION}

\subsection{The focused group and observation result and analysis}

For discussion question is "Is direction and clarification of job duties and responsibilities are required to accomplish expert activities effectively?" Most of the discussants believed that direction and clarification are useful to accomplish one's activity effectively and improve these activity progressively. Since, every leader has their vision, aim, and objectives.

For the question "Is incentives needed when experts accomplish their work effectively and vice versa?" Again most of the discussants strongly argued that when one outperformed his/her activities; should be rewarded which activates him/her to do more, on the contrary when one does his activity carelessly he/she should be punished.

To the question "Is complete freedom without any support needed for experts to do their activity better?" On the contrary, most discussants replied that complete freedom is not necessary which may lead to an unwanted 
direction. But comparative freedom is required to do varous academic activity creatively.

To question "Is some attractive inspiring support needed to have a better achievement?" Harmoniously, all discussant replied that such type of discussion and support are important to trigger experts to do their work with pleasure and feel their heads are trusted them.

For question" Is guidance and discussion with leader and elder required to achieve the quality result?" Similarly, most of the discussant viewed that the presence of guidance and discussion with the leader and elder necessary because it enable to get experience to complete duties honestly.

To question" Is setting goal together with leader necessary, surprisingly, all discussant supported that preparing goal together with the leader because it enables both parties to have common interest and achievements.

Finally, Is successive discussion and support one another with the leader is necessary to be best performer?" with one voice all discussant viewed that the presence of consecutive discussion and trust should be there to be effective. The observation also reflects the same processes that happened in the college that supports the discussion. Quantitative analysis

Table1: The mean value of the overall teaching leaning processes Descriptive Statistics

\begin{tabular}{|l|r|r|r|r|r|}
\hline & \multicolumn{1}{|c|}{$\mathrm{N}$} & \multicolumn{2}{|c|}{ Mean } & Std. Deviation & Variance \\
\cline { 2 - 6 } & Statistic & Statistic & \multicolumn{1}{c|}{$\begin{array}{c}\text { Std. } \\
\text { Error }\end{array}$} & Statistic & Statistic \\
\hline How do you rate quality of your performance? & 220 & 3.75 & .074 & 1.102 & 1.213 \\
How do you evaluate the performance of your students & 220 & 4.03 & .062 & .924 & .853 \\
How do you evaluate your satisfaction on your & 220 & 4.28 & .066 & .975 & .950 \\
teaching meet the needs of all students & & & & .991 & .983 \\
How do you evaluate the overall teaching learning & 220 & 4.27 & .067 & & \\
process in your college? & & & & & \\
Valid N (listwise) & 220 & & & & \\
\hline
\end{tabular}

As described above in Table1, one from valid respondents 220 ordered to rate their quality of performance ( very low $=1$, low $=2$, medium $=3$, good $=4$ and very good $=5$ ) the mean of their response is 3.75 (with variance 1.21 ) shows that with a slight variation all of them are good with their quality work, their student performance mean is 4.04 (variance 0.853 ) illustrated that they have done good activities and have good students performance, their satisfaction mean was 4. 28(variance 0.95 ) shows that they were satisfied with their leaders, work and the overall teaching process was 4.27 (variance 0.983 ) expresses that the overall teaching and learning environment is very good.

Table2: Correlations of students performance with teachers and other office employee satisfaction and overall processes

\begin{tabular}{|c|c|c|c|c|c|}
\hline & & $\begin{array}{l}\text { How do you } \\
\text { rate quality of } \\
\text { your } \\
\text { performance? }\end{array}$ & $\begin{array}{l}\text { How do you } \\
\text { evaluate the } \\
\text { performance of } \\
\text { your students }\end{array}$ & $\begin{array}{l}\text { How do you } \\
\text { evaluate your } \\
\text { satisfaction on } \\
\text { your teaching } \\
\text { meet the needs } \\
\text { of all students }\end{array}$ & $\begin{array}{l}\text { How do you } \\
\text { evaluate the } \\
\text { overall teaching } \\
\text { learning process } \\
\text { in your college? }\end{array}$ \\
\hline \multirow{4}{*}{$\begin{array}{l}\text { How do you rate quality } \\
\text { of your performance? }\end{array}$} & Pearson & 1 & .538 & .470 & .452 \\
\hline & Correlation & & & & \\
\hline & Sig. (2-tailed) & & .000 & .000 & .000 \\
\hline & $\mathrm{N}$ & 220 & 220 & 220 & 220 \\
\hline \multirow{3}{*}{$\begin{array}{l}\text { How do you evaluate the } \\
\text { performance of your } \\
\text { students }\end{array}$} & Pearson & .538 & 1 & .472 & .604 \\
\hline & Sig. (2-tailed) & .000 & & .000 & .000 \\
\hline & $\mathrm{N}$ & 220 & 220 & 220 & 220 \\
\hline $\begin{array}{l}\text { How do you evaluate } \\
\text { your satisfaction on }\end{array}$ & $\begin{array}{l}\text { Pearson } \\
\text { Correlation }\end{array}$ & .470 & .472 & 1 & .788 \\
\hline your teaching meet the & Sig. (2-tailed) & .000 & .000 & & .000 \\
\hline needs of all students & $\mathrm{N}$ & 220 & 220 & 220 & 220 \\
\hline \multirow{3}{*}{$\begin{array}{l}\text { How do you evaluate the } \\
\text { overall teaching learning } \\
\text { process in your college? }\end{array}$} & $\begin{array}{l}\text { Pearson } \\
\text { Correlation }\end{array}$ & .452 & .604 & .788 & 1 \\
\hline & Sig. (2-tailed) & .000 & .000 & .000 & \\
\hline & $\mathrm{N}$ & 220 & 220 & 220 & 220 \\
\hline
\end{tabular}

As can be seen on above Table2: there is a strong positive correlation of students performance $(0.472)$ with the overall teaching learning processes $(0.602)$. Demonstrated that the style of leadership positively affected both 
the students performance and the overall processes of teaching.

Table3: the Kaiser-Meyer-Olkin (KMO) and Bartlett's Test

\begin{tabular}{|lrr|}
\hline Kaiser-Meyer-Olkin Measure of Sampling Adequacy. & .758 \\
& Approx. Chi-Square & 4255.573 \\
Bartlett's Test of Sphericity & df & 276 \\
& Sig. & .000 \\
\hline
\end{tabular}

The A Kaiser-Meyer-Olkin (KMO) test is used to determine the sampling adequacy of data that are to be used for Factor Analysis. From the above Table2, it KMO is 0.758 which indicates the data is adequate to perform the operation factor analysis and $\mathrm{P}<0.05$. this also confirmed that the data is adequa(Andale, 2017; Revelle).

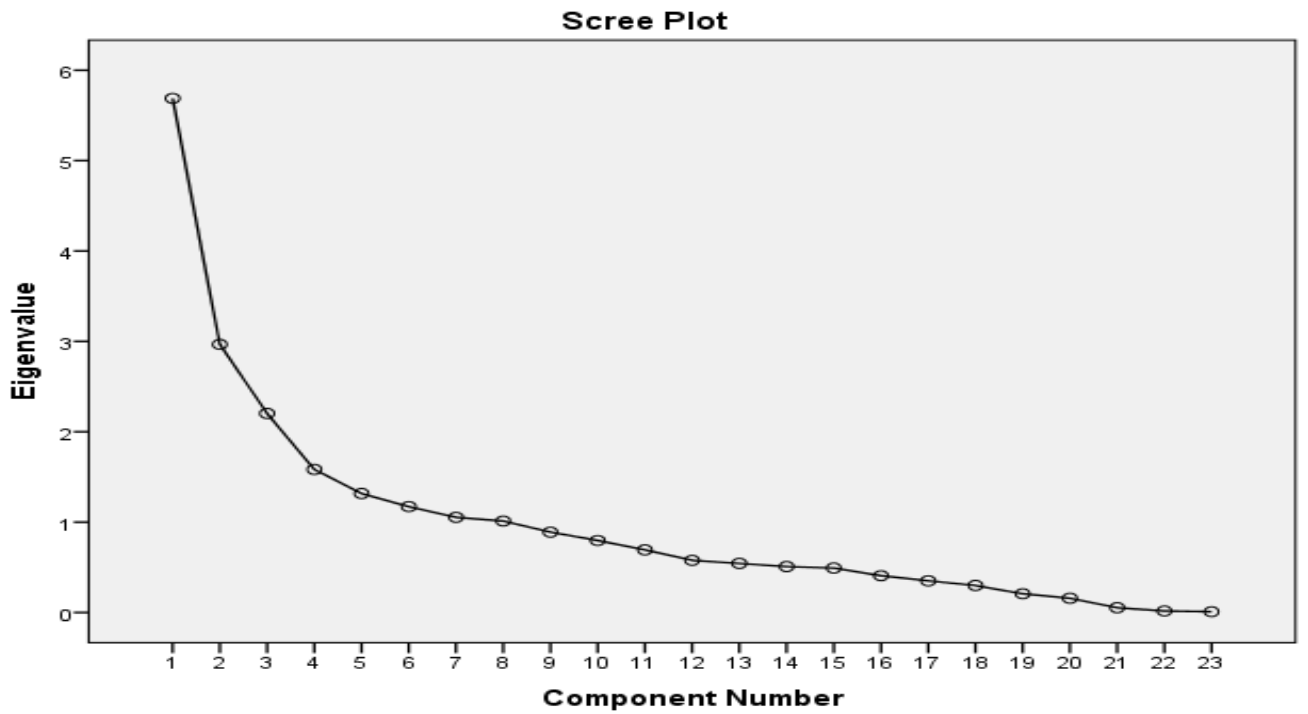

Figure 1 Scree plot

Table 4:Total Variance Explained

\begin{tabular}{|c|c|c|c|c|c|c|c|c|c|}
\hline \multirow[t]{2}{*}{ Component } & \multicolumn{3}{|c|}{ Initial Eigenvalues } & \multicolumn{3}{|c|}{$\begin{array}{l}\text { Extraction Sums of Squared } \\
\text { Loadings }\end{array}$} & \multicolumn{3}{|c|}{$\begin{array}{l}\text { Rotation Sums of Squared } \\
\text { Loadings } \\
\end{array}$} \\
\hline & Total & $\begin{array}{c}\% \text { of } \\
\text { Variance }\end{array}$ & Cumulative $\%$ & Total & $\begin{array}{c}\% \text { of } \\
\text { Variance }\end{array}$ & Cumulative $\%$ & Total & $\begin{array}{c}\% \text { of } \\
\text { Variance }\end{array}$ & Cumulative $\%$ \\
\hline 1 & 6.225 & 25.937 & 25.937 & 6.225 & 25.937 & 25.937 & 3.870 & 16.123 & 16.123 \\
\hline 2 & 3.298 & 13.742 & 39.679 & 3.298 & 13.742 & 39.679 & 2.941 & 12.253 & 28.376 \\
\hline 3 & 2.511 & 10.462 & 50.140 & 2.511 & 10.462 & 50.140 & 2.693 & 11.219 & 39.595 \\
\hline 4 & 1.432 & 5.967 & 56.108 & 1.432 & 5.967 & 56.108 & 2.529 & 10.537 & 50.132 \\
\hline 5 & 1.387 & 5.780 & 61.888 & 1.387 & 5.780 & 61.888 & 2.132 & 8.883 & 59.015 \\
\hline 6 & 1.220 & 5.085 & 66.972 & 1.220 & 5.085 & 66.972 & 1.548 & 6.450 & 65.465 \\
\hline 7 & 1.043 & 4.344 & 71.317 & 1.043 & 4.344 & 71.317 & 1.404 & 5.852 & 71.317 \\
\hline 8 & .930 & 3.874 & 75.190 & & & & & & \\
\hline 9 & .886 & 3.692 & 78.883 & & & & & & \\
\hline 10 & .828 & 3.451 & 82.334 & & & & & & \\
\hline 11 & .747 & 3.114 & 85.448 & & & & & & \\
\hline 12 & .603 & 2.512 & 87.960 & & & & & & \\
\hline 13 & .532 & 2.215 & 90.175 & & & & & & \\
\hline 14 & .449 & 1.872 & 92.047 & & & & & & \\
\hline 15 & .436 & 1.816 & 93.863 & & & & & & \\
\hline 16 & .423 & 1.763 & 95.626 & & & & & & \\
\hline 17 & .372 & 1.551 & 97.177 & & & & & & \\
\hline 18 & .282 & 1.174 & 98.351 & & & & & & \\
\hline 19 & .207 & .862 & 99.214 & & & & & & \\
\hline 20 & .080 & .331 & 99.545 & & & & & & \\
\hline 21 & .038 & .157 & 99.702 & & & & & & \\
\hline 22 & .028 & .117 & 99.819 & & & & & & \\
\hline 23 & .026 & .109 & 99.928 & & & & & & \\
\hline 24 & .017 & .072 & 100.000 & & & & & & \\
\hline
\end{tabular}

\footnotetext{
Extraction Method: Principal Component Analysis.
} 
According to the argument of principle component analysis, the most important components are the component which has eigenvalue greater that one, both the scree plot figue 1 , and Table 4 , shows there are 7 components that have eigenvalue greater than one that is covering about $71.3 \%$ of the overall variation (Abdi \& Williams, 2010; Wold, Esbensen, \& Geladi, 1987).

Table 5:Rotated Component Matrix ${ }^{\mathrm{a}}$

\begin{tabular}{|c|c|c|c|c|c|c|c|}
\hline & \multicolumn{7}{|c|}{ Component } \\
\hline & 1 & 2 & 3 & 4 & 5 & 6 & 7 \\
\hline $\begin{array}{l}\text { Teachers need to be supervised closely, or they are not } \\
\text { likely to do their work. }\end{array}$ & .075 & .163 & .177 & .137 & .914 & .078 & .085 \\
\hline $\begin{array}{l}\text { As a rule, teachers must be given rewards or punishments } \\
\text { in order to motivate them to achieve organizational } \\
\text { objectives. }\end{array}$ & .386 & .063 & .049 & .805 & .237 & .039 & .081 \\
\hline Effective leaders give orders and clarify procedures. & .396 & .068 & .068 & .807 & .208 & .014 & .081 \\
\hline $\begin{array}{l}\text { Most teachers feel insecure about their work and need } \\
\text { direction. }\end{array}$ & .119 & .270 & .254 & .272 & .199 & -.211 & -.197 \\
\hline $\begin{array}{l}\text { The leader is the chief judge of the achievements of the } \\
\text { members of the group. }\end{array}$ & .042 & -.067 & .046 & .415 & .037 & -.071 & .745 \\
\hline Leader should suggest teachers to meet set targets & -.037 & .255 & .775 & .096 & .089 & .079 & .139 \\
\hline $\begin{array}{l}\text { In complex situations, leaders should let subordinates work } \\
\text { problems out on their own. }\end{array}$ & -.078 & .774 & .101 & .060 & -.011 & .134 & -.105 \\
\hline $\begin{array}{l}\text { As a rule, leaders should allow subordinates to appraise } \\
\text { their own work. }\end{array}$ & .207 & .322 & -.105 & -.149 & .130 & .143 & .558 \\
\hline $\begin{array}{l}\text { In most situations, workers prefer little input from the } \\
\text { leader. }\end{array}$ & .378 & .572 & -.464 & .101 & .148 & .061 & .298 \\
\hline $\begin{array}{l}\text { Leaders should give subordinates complete freedom to } \\
\text { solve problems on their own. }\end{array}$ & -.083 & .739 & -.054 & -.038 & .107 & -.059 & .241 \\
\hline In general, it is best to leave subordinates alone. & .930 & .050 & .121 & .141 & .025 & .004 & .071 \\
\hline $\begin{array}{l}\text { Leader should allow teachers to do various attracting } \\
\text { technique of teaching by themselves }\end{array}$ & .169 & .795 & .107 & .141 & .133 & .066 & -.070 \\
\hline Teachers should be a part of the decision-making process. & .063 & .129 & .019 & -.126 & -.005 & .852 & .205 \\
\hline $\begin{array}{l}\text { Most workers want frequent and supportive } \\
\text { communication from their leaders. }\end{array}$ & .157 & -.029 & .630 & .137 & .198 & .134 & -.193 \\
\hline $\begin{array}{l}\text { Providing guidance without pressure is the key to being a } \\
\text { good leader. }\end{array}$ & .608 & .034 & -.016 & .303 & .155 & .161 & -.115 \\
\hline $\begin{array}{l}\text { It is the leader's job to help subordinates find their } \\
\text { "passion." }\end{array}$ & .942 & .054 & .116 & .165 & .032 & -.011 & .093 \\
\hline $\begin{array}{l}\text { Leaders need to help subordinates accept responsibility for } \\
\text { completing their work. }\end{array}$ & .122 & -.097 & .591 & .322 & .032 & .226 & -.080 \\
\hline $\begin{array}{l}\text { It is better to encourage teachers to get involved in setting } \\
\text { work goals }\end{array}$ & .119 & .133 & .113 & .157 & .324 & .640 & -.200 \\
\hline $\begin{array}{l}\text { It is better to makes others feel good by making friendly } \\
\text { environment around them. }\end{array}$ & .159 & -.076 & .744 & -.037 & .187 & -.136 & .055 \\
\hline $\begin{array}{l}\text { Teacher and students have complete trusted in their college } \\
\text { head. }\end{array}$ & .912 & .031 & .120 & .183 & .021 & -.012 & .109 \\
\hline $\begin{array}{l}\text { Heads expresses in a few simple words what teacher and } \\
\text { students could and should do. }\end{array}$ & .070 & .118 & .212 & .168 & .917 & .079 & .065 \\
\hline $\begin{array}{l}\text { Heads provides appealing images about what teacher and } \\
\text { students can do. }\end{array}$ & .258 & .255 & .306 & .619 & .023 & -.024 & .152 \\
\hline Heads and subordinates help others to improve themselves. & .390 & .571 & -.459 & .099 & .159 & .063 & .300 \\
\hline $\begin{array}{l}\text { Teacher and students cooperatively work with their college } \\
\text { head. }\end{array}$ & -.233 & -.302 & .178 & .373 & -.085 & .416 & -.115 \\
\hline
\end{tabular}

Extraction Method: Principal Component Analysis.

Rotation Method: Varimax with Kaiser Normalization.

a. Rotation converged in 9 iterations.

As indicated above in Table 5, college head, associate deans, teachers' and students monitors responses shows that the most used leadership style by the natural and computational college of Debre Berhan University is democratic and transformational leadership styles. Since these two style of leadership has shown in rotated component matrix (0.942, 0.602 and 0912,0.390) respectively. However, some elements laissez-faire and 
autocratic are also important $(0.930$ and $0.396,0.386)$ respectively. Illustrate that the most important components among the four style of leadership for genuine teaching learning processes are those which are revealed in component one with eigen value greater than one and have a component value greater than 0.350 (Bro \& Smilde, 2014). That is, during their activities expertise and professionals want their college head or leaders allow them to find their passion(0.942) which is similar to the suggestion of (Snell \& Swanson, 2000), they are also need guidance and direction from their heads without pressure which is a key to accomplish their performance according to the college aims and objectives(0.602) that is in accordance with the idea of (Moynihan \& Pandey, 2010). From transitional leadership style teacher and students want their college head have complete trusted with them (0.912) similar to (Wang, 2014), and have desires to do various activities in coordination with college head, associate heads and department heads (0.390)(Boysen et al., 2014). Moreover, from laisses fair teacher wants to have a comparative academic freedom (0.930)(Howard, 2005), and then from autocratic:- to be more efficient according to the vision and the objective of the college professionals need inspiring order and clarified procedure(0.396)(De Cremer, 2006), as well as professionals would be happy in getting reward or incentive (0.386) when they perform better and get constructive measure when they do careless activities(Van Vugt et al., 2004). Demonstrated that eventhough,democratic and transformational leadership style are dominant $(0.895,0.7140$ and 0.887,0.674); autocratic and Laissez -fairer leadership also have an important contribution( 0.930 and $0396,0.386)$.

\section{Conclusion}

Leadership is one of the fundamental functions of administration anf the behaviors of the principal vary according to the extent of their work responsibilities. College heads, associate dean and department heads have become instructional leaders, focusing on raising student achievement (Davis \& Darling-Hammond, 2012).

Most of the surveyed college discussants use their experience in the work processes. The analysis also shows that fundamental decisions are made mostly by leaders. According to the belief of majority of surveyed disscusants want their head allow them to find their passion, providing guidance without pressure and are motivated when there is rewards and incentives during when they perform their activities better.

Also they have a desire their head have complete trusted on them, want to receive constructive guide, suggestions, inspiring order and clarified procedures by leaders. Most of the workers believe the presence of punishment, the presence of consecutive discussion and support among professionals and leaders is significant to have successful team accomplishment, and there should be comparative academic freedom. Thus, it is up to the leader to select what style of leadership applies to its employees, but according to Debre Berhan university natural and computational college some of democratic and transformational as well as a few componts of laisses fair and autocratic style of leadership, bring benefits to their organization and its stakeholders.

\section{Acknowledgment}

The appreciation is due to the lecturers: Ato Gizachew Kefelew, and Dr. Belete Tewabe, for making this work a success through their various contributions, support, and encouragement both at the classroom and personal level. The support rendered by Mrs. Mastewal $\mathrm{H} / \mathrm{mariam}$ in the provision of academic advice on certain procedures of the research was appreciated. Thanks are also due to all participant of the study in the college of natural and computational science of Debre Berhan.

The acknowledgment will not be complete without mention of 2019 second-year regular Chemistry students who availed themselves as a sample that was used for this work. Thank you, all participants.

\section{REFERENCE}

Abdi, H., \& Williams, L. J. (2010). Principal component analysis. Wiley interdisciplinary reviews: computational statistics, 2(4), 433-459.

Akalu, G. A. (2014). Higher Education in E thiopia: Expansion, Quality Assurance and Institutional Autonomy. Higher Education Quarterly, 68(4), 394-415.

Akessa, G. M., \& Dhufera, A. G. (2015a). Factors that Influences Students Academic Performance: A Case of Rift Valley University, Jimma, Ethiopia Journal of Education and Practice, 16(22), 55-63.

Akessa, G. M., \& Dhufera, A. G. (2015b). Factors that Influences Students Academic Performance: A Case of Rift Valley University, Jimma, Ethiopia. Journal of Education and Practice, 6(22), 55-64.

Al-Ababneh, M. (2013). Leadership style of managers in five-star hotels and its relationship with employees job satisfaction. International Journal of Management \& Business Studies, 3(2), 93-98.

Andale, S. (2017). Kaiser-Meyer-Olkin (KMO) test for sampling adequacy. Statistics how to.

Anyango, C. A. (2015). Effects Of Leadership Styles On Employee Performance. (PhD Dissertation), The Open University Of TanzaniA, Tanzania.

Ayoko, O. B., \& Chua, E. L. (2014). The importance of transformational leadership behaviors in team mental 
model similarity, team efficacy, and intra-team conflict. Group \& Organization Management, 39(5), 504-531.

Bass, B. M., \& Riggio, R. E. (2006). Transformational leadership: Psychology press.

Beri, N., \& SHU'AIBU, M. LEADERSHIP STYLES OF SCHOOL ADMINISTRATORS AND TEACHER EFFECTIVENESS: A METANALYSIS.

Boysen, G. A., Kelly, T. J., Raesly, H. N., \& Casner, R. W. (2014). The (mis) interpretation of teaching evaluations by college faculty and administrators. Assessment \& Evaluation in Higher Education, 39(6), 641-656.

Bro, R., \& Smilde, A. K. (2014). Principal component analysis. Analytical Methods, 6(9), 2812-2831.

Chai, W., \& Kong, H. (2006). Tips for School Managers. 1-52.

Choi, S. (2007). Democratic leadership: The lessons of exemplary models for democratic governance. International journal of leadership studies, 2(3), 243-262.

Cohen, L., Manion, L., \& Morrison, K. (2005). Research Methods in Education (5 ${ }^{\text {th }}$ ed.). London and New York: RoutledgeFalmer.

Creswell, J. W. (2009). Research Design Qualitative_Quantitative and Mixed Methods Approaches (3 ${ }^{\text {rd }}$ ed.). India: SAGE Publications India Pvt. Ltd.

Davis, S. H., \& Darling-Hammond, L. (2012). Innovative principal preparation programs: What works and how we know. Planning and changing, 43, 25-45.

De Cremer, D. (2006). Affective and motivational consequences of leader self-sacrifice: The moderating effect of autocratic leadership. The Leadership Quarterly, 17(1), 79-93.

Fischer, T., Dietz, J., \& Antonakis, J. (2017). Leadership process models: A review and synthesis. Journal of Management, 43(6), 1726-1753.

Gray, D. E. (2004). Doing Research in the Real World. London Thousand Oaks New Delhi: SAGE Publications.

Hina, Q. A., \& Hussain, Z. (2019). Interplay between Leadership Styles and Effective Communication of Teachers at Higher Level. TALEEMAT, 17(1), 12-23.

Howard, W. C. (2005). Leadership: four styles. Education, 126(2), 384-392.

Ijaz Ahmad Tatlah, Iqbal, M. Z., Amin, M., \& Quraishi, U. (2014). Effect of Leadership Behaviour of Principals on Students' Academic Achievement at Secondary Level: A Comparison of the Leaders and Teachers Perceptions. Journal of Research and Reflections in Education, 8(1), 1 -12.

Iqbal, N., Anwar, S., \& Haider, N. (2015). Effect of leadership style on employee performance. Arabian Journal of Business and Management Review, 5(5), 1-6.

Karadağ, E., Bektaş, F., Çoğaltay, N., \& Yalçın, M. (2015). The effect of educational leadership on students' achievement: a meta-analysis study. Asia Pacific Education Review, 16(1), 79-93.

Karadağ, E., Çoğaltay, N., Bektaş, F., \& Yalçın, M. (2015). The effect of educational leadership on students' achievement: a metaanalysis study. Asia Pacific Education Review, 79-93. doi:10.1007/s12564-015-9357-x

Khan, I. M. S. N. (2012). Factors Affecting Students' Academic Performance. Global Journal of Management and Business Research, 12(9), 16-22.

Kumpulainen, K., Kajamaa, A., \& Rajala, A. (2018). Understanding educational change: Agency-structure dynamics in a novel design and making environment. Digital Education Review(33), 26-38.

Manning, K. (2017). Organizational theory in higher education: Routledge.

Martirosyan, N. M., Saxon, D. P., \& Wanjohi, R. (2014). Student Satisfaction and Academic Performance in Armenian Higher Education. American International Journal of Contemporary Research, 4(2), 1-5.

Mishra, S. (2006). Quality Assurance in Higher Education An Introduction. Bangalore, India: National Assessment and Accreditation Council.

Mlingwa, L. (2015). Contributions of secondary school head teachers' leadership styles on teachers' ${ }^{\prime}$ work performances in Geita urban district. The University of Dodoma.

Moynihan, D. P., \& Pandey, S. K. (2010). The big question for performance management: Why do managers use performance information? Journal of public administration research and theory, 20(4), 849-866.

Nielsen, K., Yarker, J., Brenner, S. O., Randall, R., \& Borg, V. (2008). The importance of transformational leadership style for the well-being of employees working with older people. Journal of advanced nursing, 63(5), 465-475.

Ojokuku, R., Odetayo, T., \& Sajuyigbe, A. (2012). Impact of leadership style on organizational performance: a case study of Nigerian banks. American journal of business and management, 1(4), 202-207.

Ouma, M., Lucy, A. E., \& John, A. O. (2015). Effect of Principals' Leadership Styles on Students Academic Performance in Public Secondary Schools in Homa-Bay County, Kenya.

Potocki, K. A., \& Brocato, R. C. (1995). A System of Management for Organizational Improvement. Johns Hopkins Apl Technical Digest,, 16(4), 402-412.

Revelle, W. KMO: Find the Kaiser, Meyer, Olkin Measure of Sampling Adequacy.

Robinson, V. (2007). The impact of leadership on student outcomes: Making sense of the evidence. Australian Council for Educational Research, 12-16.

S.Nanjundeswaraswamy, T., \& Swamy, D. R. (2014). Leadership styles. Advances In Management, 7(2), 57-62. 
Sheshi, A., \& Kërçini, D. (2017). The role of Transactional, Transformational and Participative Leadership in performance of SME's in Albania. Albanian Journal of Agricultural Sciences, 285-292.

Silva, A. (2016). What is leadership? Journal of Business Studies Quarterly, 8(1), 1.

Snell, J., \& Swanson, J. (2000). The Essential Knowledge and Skills of Teacher Leaders: A Search for a Conceptual Framework.

Sun, J., \& Leithwood, K. (2015). Direction-setting school leadership practices: A meta-analytical review of evidence about their influence. School Effectiveness and School Improvement, 26(4), 499-523.

TS, N., \& Swamy, D. (2014). Leadership styles. Advances In Management Vol, 7, 2.

Vaismoradi, M., Bondas, T., Salsali, M., Jasper, M., \& Turunen, H. (2014). Facilitating safe care: a qualitative study of Iranian nurse leaders. Journal of nursing management, 22(1), 106-116.

Van Vugt, M., Jepson, S. F., Hart, C. M., \& De Cremer, D. (2004). Autocratic leadership in social dilemmas: A threat to group stability. Journal of experimental social psychology, 40(1), 1-13.

Wang, T. R. (2014). Formational turning points in the transition to college: Understanding how communication events shape first-generation students' pedagogical and interpersonal relationships with their college teachers. Communication Education, 63(1), 63-82.

Wold, S., Esbensen, K., \& Geladi, P. (1987). Principal component analysis. Chemometrics and intelligent laboratory systems, 2(1-3), 37-52.

Zvavahera, P. (2014a). The effect of leadership on service delivery in universities. Research in Higher Education Journal, 1-8.

Zvavahera, P. (2014b). The effect of leadership on service delivery in universities. 